\title{
Edible spineless cactus (Opuntia ficus-indica): A promising alternative forage source for livestock
}

\author{
Anupam Thakuria ${ }^{1}$, Chander Datt $^{1}$, Shambhvi $^{1}$, Kuldeep Dudi $^{1}$, Gajender $^{2}$, PThamizhan and RK Yadav $^{2}$
}

Received: 06 May 2020 / Accepted: 18 May 2020 / Published online: 12 July 2020

(C) Indian Dairy Association (India) 2020

\begin{abstract}
Spineless cactus (Opuntia fcus-indica) is a fast growing xerophytic plant well adapted to arid conditions. It remains green even during summer and can serve as a feed resource during scarcity. Its productivity is high in fertile soils and with irrigation facilities but it also grows in poor soils and with little water. It doesn't need well-drained soils and tolerates salinity to a higher extent. Cactus can produce a biomass of 20200 tonnes DM/ha/year. Cactus pear has the advantage of being a source of water for animals particularly during the dry season. The adaptations enable cactus to convert water 4-5 times more efficiently to DM than the most efficient grasses. Cactus cladodes are high in water, sugars, ash, vitamins $\mathrm{A}$ and $\mathrm{C}$ but they are low in crude protein and fibre. They exhibit a high $\mathrm{Ca}$ : $\mathrm{P}$ ratio and are highly palatable. Spineless cactus can be used as a source of alternative green fodder for the livestock particularly in small ruminants and has the capability to combat extreme draught conditions with round the year availability. Though many varieties/clones of spineless cactus have been developed but their potential as animal feed need to be investigated further.
\end{abstract}

Keywords: Alternate feedstuff, Nutrient utilization, Production performance, Ruminants, Spineless cactus

\section{Introduction}

In India, there is deficit of $44 \%$ of concentrate feed ingredients, $35.6 \%$ of green fodders and $10.95 \%$ of dry roughages (IGFRI, Vision 2050). The government labels $30 \%$ of India's landmass as

\footnotetext{
${ }^{1}$ Animal Nutrition Division, ICAR-National Dairy Research Institute, Karnal-132 001, Haryana, India

${ }^{2}$ Agronomy Department, ICAR-Central Soil Salinity Research Institute, Zarifa Farm, Kachhwa Road, Karnal-132 001, Haryana, India
}

Chander Datt $(\bowtie)$

Animal Nutrition Division, ICAR-National Dairy Research Institute, Karnal-132 001, Haryana, India

E-mail: chandatt@gmail.com wasteland. Against the backdrop of ongoing climate change, frequent and long droughts, land degradation and green fodder scarcity, spineless cactus (Opuntia fcus-indica) can be a promising alternative fodder for livestock as it is palatable (Russell and Felker, 1987).

Spineless cactus is a fast growing xerophytic plant well adapted to arid conditions. It remains green even during summer and can be used as a feed during scarcity. Cactus belongs to the family Cactaceae assimilating about 130 genera. It is highly resilient and has high water use efficiency and capability to grow in poor and degraded soils where other plants fail to grow. Cactus is vegetatively propagated and cladodes are used for this purpose. Cactus pear has the advantage of being a source of water for animals particularly during the dry season. It is tolerant to poor soil conditions and produces high biomass yield (Russell and Felker, 1987). Cactus is able to convert water 4-5 times more efficiently to dry matter (DM) than the most efficient grasses (Russell and Felker, 1987). These and other attributes such as ability to remain succulent during drought and produce forage, fruit and other useful products as well as its capacity in preventing long-term degradation of ecologically weak environments have increased the importance of cactus in arid and semi-arid regions. Ruminants adapted to these areas can make efficient use of non-conventional feed resources like Opuntia ûcus-indica (Khanum et al. 2007). Different parts of edible cactus have been shown to have antioxidant, anti-inflammatory, anti-diabetic and anti-cholestrogenic activities (Kauthale et al. 2017). Therefore, an attempt has been made to cover aspects like its production and potential as ruminant feed encompassing its effect of inclusion in the ration on feed intake, nutrient utilization and production performance.

\section{Distribution and production of cactus}

Mexico is considered as the centre of cactus origin. Cactus is available in a range of environments from sea level in the Californian deserts to an altitude of $4700 \mathrm{~m}$ (above mean sea level) in the Peruvian Andes and from tropical areas of Mexico with temperatures greater than $5^{\circ} \mathrm{C}$ to parts of Canada where temperature reaches as low as $-40^{\circ} \mathrm{C}$ (Makkar, 2017). It is cultivated in America, Asia, Africa, Europe and Oceania. Argentina has about 
1650 ha under cactus cultivation. Brazil has 500000 ha area under cactus production, Chile covers 935 ha while Mexico has a cultivated area of 54000 ha and a large area ( 3 million ha) under cactus in the wild as natural plantation. Other countries in America that have cactus plantation are Peru and Bolivia. Brazil and Bolivia use cactus mainly as a fodder crop while Chile, Argentina and Mexico use it for fruit production. Cactus in Peru is used mainly (60\%) for production of red dye and the remaining $40 \%$ for fruit production. Mexico has started using more intensive production practices, i.e. adoption of drip irrigation and cultivation in more benign areas with better quality soil and good rainfall conditions and use of mechanical fruit cleaning. In Africa, cactus is cultivated in Algeria (30000 ha), Ethiopia (360000 ha, $66 \%$ being spiny cactus) and Morocco (120000 ha). South Africa has approximately 4500 ha for fruit (33\%) and fodder (67\%) production. Cactus area covered in Tunisia is approximately 600000 ha used mainly for fruit production.

In West Asia, Jordan (300 ha), Lebanon, Syria, Gulf countries (Oman, Qatar, Saudi Arabia, the United Arab Emirates and Yemen) and Israel (350 ha) cultivate cactus. In Europe, it is cultivated in Italy (15000 ha), Portugal (200 ha) and Spain. In some countries, cactus cladodes obtained on pruning the cactus orchards established for fruit production are also used for livestock feeding. This has enabled integration of livestock into the cactus production which brings back nutrients and organic matter to cactus cultivation through manure and also complements farmers' income. Due to lack of information on the area under cactus cultivation, it is difficult to assess precisely the importance of cactus in different livestock production systems (Makkar, 2017).

Its productivity is high in fertile soils and with irrigation facilities. It also grows in poor soils and with little water. It doesn't need well-drained soils and tolerates salinity to a higher extent. Cactus can produce a biomass of 20-200 tonnes DM/ha/year (FAO, 2017). With such high biomass yield (60-fold increase over rangeland productivity), it is possible to produce sufficient forage to sustain 4-5 cows per year. In India, commercial cultivation of cactus is yet to start. During the last two decades the research was conducted by many institutes in India especially those in arid and semi-arid regions but the outcome of this work is yet reach to the farmers (Kumar et al. 2018). Cacti can produce 4-5 times DM (Degu et al. 2009) per mm of rainfall than any other type of plant due to their crassulacean acid metabolism(Guevara et al. 2011).

Different clones/varieties of edible cactus (Fig. 1, 2) such as 1269, 1270, 1271, 1280, 1281, 1308, CAZRI Botanical Garden, Mount Abu, 1458, AHCP-2 etc. have been developed (Soni et al. 2015). The study conducted at ICAR-Central Soil Salinity Research Institute, Karnal, Haryana, India showed that amongst the clones of edible cactus, the highest survival was found in clone 1271 (67\%) followed by $1270(65 \%), 1280(64 \%)$ and the least in clone 1287 (48\%). Clone 1270 took the least time of 69-72 days to sprout followed by 1271 ( 85 to 96 days) and 1280 (93 to 98 days) while the maximum time taken to sprout was found in the case of clone 1287 (97 to 110 days). Clone 1271 had significantly larger plant height followed by 1280 under different planting methods but clone 1270 recorded more plant height followed by 1271 with variable irrigation treatments. Over all, clone 1287 was shortest among the four clones. The clone (1280) performed well at all the salinity levels but plant height and number of cladodes formation were reduced with increase in salinity from normal $(0 \mathrm{mM})$ to 32 $\mathrm{mM}$ and then to $52 \mathrm{mM}$ (Singh et al. 2014).

\section{Edible spineless cactus as animal feed}

Long dry seasons, characterized by shortage of animal feed, both in quality and quantity are the major factors that affect animal production. The low nutritive value of the forage during the dry season is the main obstacle to increasing animal productivity (Abidi et al. 2009). Use of non-conventional feed resources that are available and adapted in dry areas and use water more efficiently can be the best option to ensure viability of livestock in these drought prone areas. Ruminants adapted to these areas can make efficient use of nonconventional feed resources like Opuntia fcus-indica (Khanum et al. 2007).

There are different types of Opuntia spp. namely native thorny, less thorny, thorn-less and regular type. All the four varieties are palatable with variable nutrient composition. They exhibit different acidic $\mathrm{pH}$ of 5.53, 5.27, 5.09 and 5.55, respectively. The native thorny and less-thorny varieties are adapted well to semiarid regions like Rajasthan, Haryana, Maharashtra and other states. ICAR- Central Arid Zone Research Institute, Jodhpur has successfully established a thornless variety of cactus called 'CAZRI Botanical Garden' with very good yield and palatability to livestock (Kumar et al. 2017). However, cactus cladodes have high water content which results in high ruminal degradability and laxative effects when fed alone (Ben Salem et al. 2004, Souza et al. 2009, Santos et al. 2010) but this laxative action has no detrimental effect on the animal's health. It is the result of a fast passage through the digestive system (De Kock, 2001). Also, O. $\hat{u}$ cus-indica cladodes are not nutritionally balanced as it is low in crude protein, ûbre, phosphorus and sodium (Souza et al. 2009). The low CP content may affect its use as a complete feed as it may cause protein deficiency in livestock. Ensiling it with dried forage legumes could increase DM content making it suitable for ruminant feeding.

\section{Chemical composition of edible spineless cactus}

The cactus cladodes are high in water, sugars, ash, vitamins A and $\mathrm{C}$ but they are low in crude protein and fibre (Ben Salem et al. 1996, Batista et al. 2003). They exhibit a high $\mathrm{Ca}$ : $\mathrm{P}$ ratio and are highly palatable (Nefzaoui and Ben Salem, 2001). Cladodes (1 to 3 year) are high in water during winter and spring (85-90\%), less 


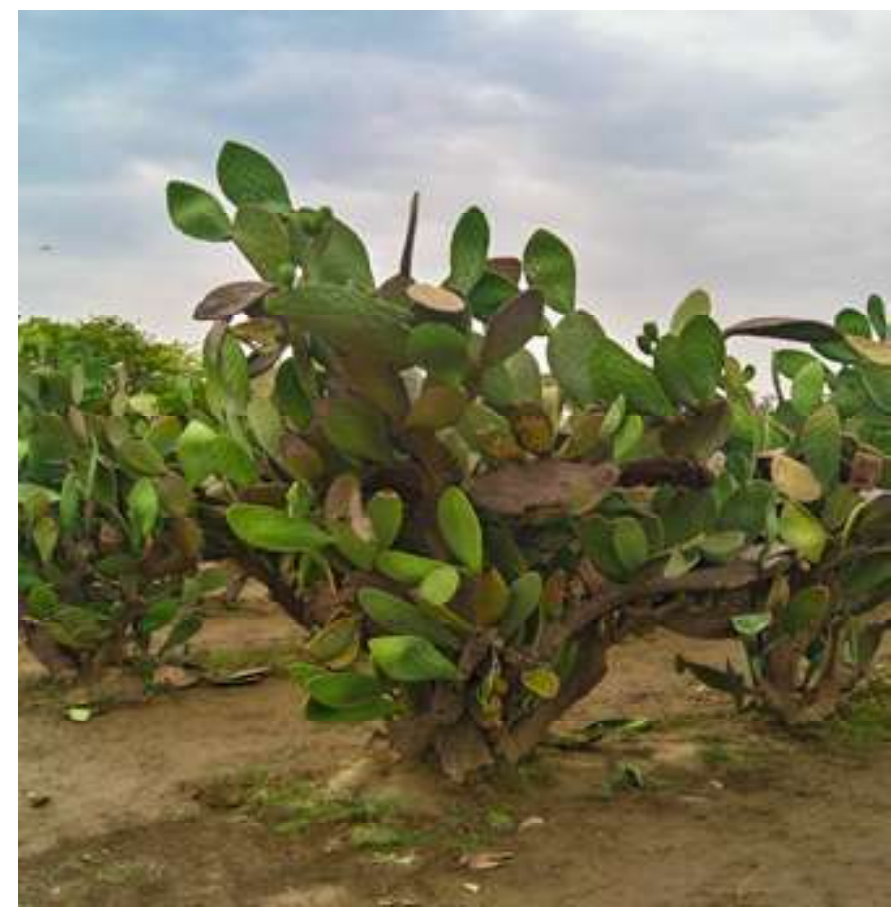

Fig. 1 Edible spineless cactus

in summer (75-85\%). Younger cladodes have higher water content (Le Houérou, 1996). Cladodes as forage can solve the problem of livestock watering but attention should be paid to their low DM content with regard to diet composition. To compensate for low DM content, the ruminant consumes large quantities of cladodes which may lead to diarrhoea. It is, therefore, recommended to include a fibrous feedstuff and appropriate supplements particularly N richer ones. De Kock (2001) reported that penned sheep could be kept alive for 500 days without drinking water provided they had free access to fresh cactus. Compared with conventional feedstuffs, Opuntia cladodes have high ash content. Depending on the species and cultivar, the ash content

Table 1 Chemical composition (\% DM basis) of different accessions of spineless cactus

\begin{tabular}{llllc}
\hline Parameter & & \multicolumn{3}{c}{ Cactus accession } \\
\hline & 1270 & 1271 & 1280 & 1308 \\
Dry matter & 7.51 & 7.95 & 11.44 & 11.15 \\
Crude protein & 6.09 & 5.48 & 5.45 & 5.33 \\
Crude fibre & 11.57 & 13.73 & 17.22 & 20.66 \\
Ether extract & 2.54 & 1.98 & 2.60 & 1.60 \\
Ash & 13.11 & 18.05 & 12.10 & 12.95 \\
Silica & 1.23 & 1.01 & 1.65 & 0.96 \\
NDF & 26.34 & 26.52 & 26.43 & 25.26 \\
ADF & 17.66 & 18.24 & 17.42 & 17.16 \\
Ca & 0.53 & 0.47 & 0.50 & 0.53 \\
P & 0.36 & 0.41 & 0.38 & 0.37 \\
$\mathrm{~K}$ & 0.27 & 0.26 & 0.29 & 0.30 \\
$\mathrm{Mg}$ & 0.11 & 0.10 & 0.09 & 0.10 \\
$\mathrm{Na}$ & 0.20 & 0.19 & 0.22 & 0.21 \\
\hline
\end{tabular}

ranges from $10-25 \%$ on DM basis. Calcium followed by $\mathrm{K}$ is the most abundant mineral in the cladodes but the availability of $\mathrm{Ca}$ to rumen microflora and the host animal is compromised by the high content of oxalates and the extremely high Ca: $\mathrm{P}$ ratio (Sawyer et al. 2001).

Cactus cladodes are high in carbohydrates $(60 \%)$ and $\beta$-carotene $(6.5 \mathrm{mg} / \mathrm{kg} \mathrm{DM})$ as per reports (Ayadi et al. 2009, FAO, 2017). Mucilage level is high in the cladodes of spineless $(6-13 \mathrm{~g} / \mathrm{kg}$ fresh material) and spiny (6-14 g/kg fresh material) cactus (Abidi et al. 2009). Mucilage concentration increases at least twofold in summer compared to winter. It reduces salivation in ruminants thus avoiding a rapid decrease in rumen $\mathrm{pH}$. In general, neutral detergent fibre (NDF) ranges from $18-30 \%$ on DM basis although the cladodes of a spiny cactus (Opuntia imbricate) contain $40 \%$ NDF. 12-20\% acid detergent fibre (ADF) and 1.5-4.0\% lignin. Carotenes, titratable acidity and carbohydrate contents increase during development while protein and fibre levels decrease. Cladodes are high in malic acid and its content fluctuates due to a CAM-based diurnal rhythm (FAO, 2017). Salem et al. (2004) reported that cactus cladodes contained $17.7 \% \mathrm{DM}$. The concentration of OM, TDN, CP, NDF, ADF, ADL, Ca, P, Na, K and $\mathrm{Mg}$ were 76.2, 65.0, 4.6, 33.8, 16.8, 5.2, 5.21, 0.1, 0.06, 2.6 and $1.09 \%$, respectively. The levels of $\mathrm{Cu}, \mathrm{Fe}, \mathrm{Mn}$ and $\mathrm{Zn}$ were 6.5 , $170.8,248.9$ and $31.0 \mathrm{ppm}$, respectively. The nutritional evaluation of four cactus accessions namely 1270,1271, 1280 and 1308 was undertaken at BAIF laboratory, Urulikanchan, Maharashtra and is given in the Table 1 (Kauthale et al. 2017).

\section{Effect of inclusion of edible spineless cactus in diet on DM intake}

Sirohi et al. (1996) indicated that cactus was preferred by the animal over the conventional roughages like cenchrus hay and baru grass (Sorghum halepense). Total DM intake was the least in animals offered the highest level of cactus DM inclusion compared to the other treatments (Gebremariam et al. 2006).

Sheep supplemented with cotton seed cake and peanut cake had higher intake of cactus and tef straw DM than those supplemented with noug (Guizotia abyssinica) seed cake. Moreover, cotton seed cake and peanut cake promoted higher $\mathrm{DM}$ and OM intake compared to noug seed cake and the control treatment (Degu et al. 2009). Thus, supplementation increased total $\mathrm{CP}$ intake. Mixing cactus and browse in silage making improved both DM and $\mathrm{N}$ content in the product (Gusha et al. 2015). Cactus can serve as a link between legume forage and hays by supplying a degradable source of OM. Also, cactusbrowse silages improved microbial protein flow to the lower gut for digestion thus increasing amino acid supply for maintenance, growth and production. Poor quality roughage utilization was improved with the addition of cactus-browse silages as supplements. These silages could be used in livestock feeding to improve livelihood in drier and resource constrained farming sections. 
Spineless cactus can be an alternative feed in semi-arid regions replacing up to $80 \%$ of wheat bran in sheep diet without affecting DM intake (Lins et al. 2016). Spineless cactus plus urea was found to be a useful alternative feed option in semi-arid regions during the shortage of feed and water in prolonged drought. Spineless cactus could replace up to $80 \%$ of wheat bran in sugarcane-based diets for sheep promoting a higher intake of DM and TDN and consequently could reduce dependence on feed concentrates and the feeding costs (Lins et al. 2017). Makkar (2017) reported that $70 \%$ cactus and 30\% concentrate could maintain a cow with daily milk yield of $20 \mathrm{~L}$. The effect of replacement of $1 / 3^{\text {rd }}$ dietary DM through Opuntia on DM intake and digestibility in sheep (Kumar et al. 2017) has been shown in Table 2 .

\section{Effect of edible spineless cactus on nutrient utilization and rumen fermentation}

Salem et al. (2005) reported that barley diet and cactus diet showed similar OM digestibility, however, CP digestibility was lower in cactus diet. Dry matter intake and total tract apparent digestibility of DM, OM, CP and GE were lower in sheep fed Opuntia + Cenchrus hay diets than those on Cenchrus hay + Concentrate or Opuntia + Cenchrus hay + GN cake diets which were similar (Mishra et al. 2006). The NDF and ADF digestibility were similar in different groups. However, Opuntia +Cenchrus hay + GN cake diets had lower cellulose digestibility than Opuntia + Cenchrus hay diets than those on Cenchrus hay + Concentrate diets which showed similar digestibility values. The inclusion of cactus upto $24-36 \%$ in diets had pronounced effects on feed and water intake and urine excretion in Dorper wethers (Menezes et al. 2010). Due to its relatively high soluble carbohydrate and low fibre contents, inclusion of sun-dried Opuntia cladodes in diets increased the digestibility (particularly DM) and tended to stimulate voluntary intake. Despite an increase in the watery fresh faeces, less faecal DM was excreted. De-Kock (1980) reported that this laxative action due to high mucilage content is not a disease symptom and has no detrimental effect on the animal's health but it is due to faster passage through the digestive system.

The digestibility of Opuntia cladodes is comparable with high quality hay (Shoop et al. 1977). The replacement of wheat bran by spineless cactus provided a higher nutrient intake explained by the concentration of easily fermentable carbohydrates and lower indigestible NDF content of diets promoting better dry matter digestibility (Lins et al. 2016). The plant is extremely variable in its nutritive value which depends mainly on species, variety, age of plant, season and plant part (Hanselka and Paschal, 1990). Sirohi et al. (1997) showed that Opuntia from semi-arid regions in India contained 9.2\% CP which is higher than the commonly used dry roughages (straw, strovers and grasses) in ruminant feeding. Although Opuntia feeding with conserved fodder maintained adult sheep, however, high $\mathrm{N}$ loss in urine led to negative $\mathrm{N}$ balance (Sirohi et al. 1997).

The faecal $\mathrm{N}$ loss was higher in lambs than kids and higher with barley than cactus diets (Abidi et al. 2009). The amount of $\mathrm{N}$ voided in urine was not affected by supplement type and animal species. Replacement of wheat bran with spineless cactus did not alter $\mathrm{N}$ loss from faeces. However, there was a quadratic effect on $\mathrm{N}$ loss from urine representing approximately $19.7 \%$ of the ingested $\mathrm{N}$ in the diets with spineless cactus plus urea. The maximum $\mathrm{N}$ loss from urine was estimated with a $70.3 \%$ replacement of wheat bran (Lins et al. 2017).

The total $\mathrm{N}$ content of ruminal ûuid was the highest in Opuntia + Cenchrus hay + GN cake diet compared to Opuntia + Cenchrus hay and Cenchrus hay + concentrate diet. Opuntia feeding increased ruminal $\mathrm{pH}$ but decreased total volatile fatty acid (TVFA) and fractional VFA concentration (Mishra et al. 2006). Supplemented groundnut meal improved ruminal $\mathrm{N}$ and $\mathrm{NH}_{3}-\mathrm{N}$ whereas impaired microbial $\mathrm{N}$ supply needs further research to optimize $\mathrm{P}$ and other nutrient supplements for better animal performance. There was a reduction in microbial protein synthesis at above $46 \%$ replacement of wheat bran with spineless cactus (Lins et al. 2017) which could be due to greater amount of urea added to the diets. The lower microbial protein production with replacement of $100 \%$ of wheat bran could be explained by the presence of low ruminal digestibility of fibre of sugarcane resulting in lower energy available for rumen bacteria.

\section{Effect of edible spineless cactus on blood parameters}

Blood Ca concentration was affected by the supplementation of cactus and barley at 1 week prior to and at 2 weeks after lambing. The ewes supplemented with cactus had a higher concentration

Table 2 Effect of replacement of dietary DM through Opuntia, on DM intake and digestibility in sheep

\begin{tabular}{lllc}
\hline Experimental Group $(\mathrm{n}=8)$ & $\begin{array}{l}\text { DMIntake } \\
(\% \text { of body weight })\end{array}$ & $\begin{array}{l}\text { DM Intake } \\
(\mathrm{g} / \mathrm{kg} \mathrm{W} \text { ) } \\
\text { weight })\end{array}$ & $\begin{array}{l}\text { DM } \\
\text { digestibility } \\
(\%)\end{array}$ \\
\hline Opuntia* + Green Napier & 3.39 & 79.32 & 61.49 \\
Opuntia* + Berseem hay & 4.15 & 100.11 & 62.00 \\
Opuntia* + Lathyrus straw & 4.35 & 101.71 & 60.09 \\
Opuntia* + gram straw & 3.45 & 82.24 & 55.95 \\
\hline
\end{tabular}

$* 1 / 3^{\text {rd }}$ dietary DM was replaced through Opuntia 
of Ca than ewes supplemented with barley (Rekik et al. 2010). They also reported that plasma glucose concentrations at 2 weeks prior to lambing were higher in ewes that were supplemented with cactus and the situation was reversed 2 weeks after lambing, the ewes supplemented with barley having a higher plasma glucose concentration. However, insulin level was lower in ewes of both feeding regimes and not different at any sampling time with no clear trend before or after lambing. Nitrogen retention increased by $0.10 \mathrm{~g} / \mathrm{d}$ while plasma urea nitrogen (PUN) increased by $0.20 \mathrm{mg} / \mathrm{d}$ for every $1 \%$ level of replacement of wheat bran with spineless cactus in sugarcane based diet (Lins et al. 2017). Despite the gradual increase in PUN, toxicity was not recorded in the animals that received up to $39.4 \mathrm{~g}$ urea $/ \mathrm{kg}$ ration. However, above $31.6 \mathrm{~g} / \mathrm{kg}$ of supplied urea, there was a reduction in DM intake with $80 \%$ replacement.

\section{Effect of inclusion of edible spineless cactus in rations on production performance}

Inclusion of cactus in the diet or other comparable diets up to $50 \%$ on DM basis for sheep fed tef straw promoted weight gain without causing digestive disturbances common in diets with high cactus inclusion (Gebremariam et al. 2006). Cactus supplementation with cottonseed cake and peanut cake resulted in higher daily BW gain than the non-supplemented sheep. Sheep supplemented with cactus alongwith cottonseed cake had higher slaughter weight and dressing percentage on empty BW basis than the non-supplemented ones. They opined that the basal diet consisting of cactus and tef straw promoted body weight gain in sheep indicating their usefulness under conditions of feed scarcity (Degu et al. 2009).

Forage cactus meal showed the capability of replacing ground corn in the diet of ovines without affecting biological yield and weighted value of prime and choice cuts or the yield of viscera and organs (Santos et al. 2011). The results on use of cactuslegume diets were comparable to those of commercial diet (Gusha et al. 2015). Provision of cheaper quality protein from browse hay and readily fermentable sugar from cactus to animal feeding on poor quality roughage had improved roughage intake. Slaughter weight could be reached earlier if these supplements were used leading to higher and quick turn over in goats production. Gusha et al. (2015) reported that throughout $1^{\text {st }}$ month of life, lambs born to barley and cactus fed ewes had a similar growth pattern. At 10 days of age, cactus fed lambs weighed $6.8 \mathrm{~kg}$ compared with 6.2 $\mathrm{kg}$ for barley lambs. At 30 days of age, average BW of lambs of both treatments was $9.5 \mathrm{~kg}$. Cactus feeding in Osmanabadi kids also enhanced the performance of kids in terms of total body weight gain and average daily gain in body weight without any adverse effect (Kauthale et al. 2017). Spineless cactus could be included up to the level of $30 \%$ on DM basis in the finishing diets of lambs to increase the fat content of meat without compromising its sensorial properties (Lima et al. 2019).
Cactus fed ewes tended to accumulate more colostrum at birth and yielded higher colostrum at $24 \mathrm{~h}$ than barley fed ewes (Rekik et al. 2010). The milk yield at 10 days from lambing in ewes receiving the barley and cactus based diets averaged 1441 and $1580 \mathrm{~g} / \mathrm{d}$, respectively. For both feeding regimes, milk yield decreased at 30 days to 1030 and $1041 \mathrm{~g} / \mathrm{d}$ for barley and cactus based diet fed ewes, respectively. Lipid extracted from animals on the cactus diet contained more C18:2 and conjugated linoleic acid (CLA). The composition was similar for the other fatty acids. Furthermore, animals fed cactus based diet showed a higher proportion of poly-unsaturated fatty acid (PUFA) and PUFA: SFA ratio than those in the control group (Atti et al. 2006). The lipid content of the goat milk underwent a linear reduction (3.84 to $2.97 \%$ ) with the substitution of corn meal by cactus pear (Costa et al. 2010). The milk total solids content decreased linearly with the substitution of the energetic concentrate by cactus ranging from 12.08 to $10.76 \%$. The percentages of medium-chain SFA in goat milk increased linearly with the substitution of corn meal by cactus pear. The total fatty acid concentration in the goat milk also increased linearly with the substitution of corn meal for cactus pear ranging from 62.80 to $71.93 \%$. While mono-unsaturated fatty acid (MUFA) presented a linear reduction with values ranging from 26.73 to $16.11 \%$, while the total PUFA concentration in goat milk did not change that averaged $2.30 \%$.

Cactus feeding reduced proportion of stearic and oleic acids but did not affect linoleic (C18:2) and linolenic (C18:3) acids. Abidi et al. (2009) found that cactus diet increased the accumulation of trans-11C18:1 as compared to the meat from the animals fed the barley-based diet. Feeding cactus resulted in a lower percentage of n-3 fatty acids in sheep compared to goats. Despite the higher level of total n-6 fatty acids in kid meat, the n-6/n-3 ratio had a very low value which is favourable for human health.

\section{Conclusions}

Edible spineless cactus can be grown easily in the lands with low water content due to its higher water conversion efficiency. Moreover, it has more tolerance to higher soil salinity. Therefore, growing cactus as a forage source for livestock can lead to a proper utilization of waste lands. Nutritional value of spineless cactus cladode is almost similar to some of the other conventional cereal fodders. Use of its cladodes as ruminant forage source reduces the water requirement as its cladodes are significantly high in moisture content which is of significance to the livestock farmers particularly in draught prone areas. Therefore, edible spineless cactus could be an alternate source of green fodder for livestock particularly small ruminants with due supplementation of nutrients especially protein, however, nutritional worth of different clones/varieties in different ruminant species need to be evaluated for formulation of balanced rations. 


\section{References}

Abidi S, Ben Salem H, Martín-García AI, Molina-Alcaide E (2009) Ruminal fermentation of spiny (Opuntia amyclae) and spineless (Opuntia ûcusindica $f$. inermis) cactus cladodes and diets including cactus. Anim Feed Sci Technol 149: 333-340

Abidi S, Ben Salem H, Vasta V, Priolo A (2009) Supplementation with barley or spineless cactus (Opuntia ficusindica f.inermis) cladodes on digestion, growth and intramuscular fatty acid composition in sheep and goats receiving oaten hay. Small Rumin Res 87: 9-16

Atti N, Mahouachi M, Rouissi H (2006) The effect of spineless cactus (Opuntia ûcus-indicaf. inermis) supplementation on growth, carcass, meat quality and fatty acid composition of male goat kids. Meat Sci 73: 229-235

Ayadi MA, Abdelmaksoud W, Ennouri M, Attia H (2009) Cladodes from Opuntia ficusindica as a source of dietary fiber: Effect on dough characteristics and cake making. Indust Crops Prod 30: 40-47

Batista AMV, Mustafa AF, Santos GRA (2003) Chemical composition and ruminal dry matter and crude protein degradability of spineless cactus. J Agron Crop Sci 189: 123-126

Ben Salem H, Abdouli H, Nefzaoui A, El-Mastouri A, Ben Salem L (2005) Nutritive value, behaviour and growth of Barbarine lambs fed on oldman saltbush (Atriplex nummularia L.) and supplemented or not with barley grains or spineless cactus (Opuntia ûcus-indica f. inermis) pads. Small Rumin Res 59: 229-237

Ben Salem H, Nefzaoui A, Ben Salem L (2002) Supplementation of Acacia cyanophylla Linn. foliage based diets with barley or shrubs from arid areas (Opuntia ûcusindica f. inermis and Atriplex nummularia L.) on growth and digestibility in lambs. Anim Feed Sci Technol 96: 1530

Ben Salem H, Nefzaoui A, Ben Salem L (2002) Supplementing spineless cactus (Opuntia ûcus-indicaf. inermis) based diets with urea-treated straw or oldman salt bush (Atriplex nummularia): Eûects on intake, digestion and sheep growth. J Agric Sci Camb 138: 85-92

Ben Salem H, Nefzaoui A, Ben Salem L (2004) Spineless cactus (Opuntia ûcus-indica f. inermis) and oldman saltbush (Atriplex nummularia L.) as alternative supplements for growing Barbarine lambs given straw-based diets. Small Rumin Res 51: 65-73

Costa RG, Beltrão Filho EM, do Egypto RDCR, Madruga MS, de Medeiros AN, de Oliveira CJB (2010). Chemical composition of milk from goats fed with cactus pear (Opuntia ficus-indica L. Miller) in substitution to corn meal. Small Rumin Res 94: 214-217

De Kock GC (2001) The use of Opuntia as a forage source in arid areas of Southern Africa. In: Cactus (Opuntia spp) as Forage. FAO Plant Production and Protection Paper 169, Food and Agriculture Organization of the United Nations, Rome (Mondragón-Jacobo, C., Pérez-González, S.; eds.)

De Kock GC (1980) Drought resistant fodder shrub crops in South Africa. International Livestock Center for Africa, Ethiopia

Degu A, Melaku S, Berhane G (2009) Supplementation of isonitrogenous oil seed cakes in cactus (Opuntia ûcus-indica)-tef straw (Eragrostistef) based feeding of Tigray Highland sheep. Anim Feed Sci Technol 148: 214-226

FAO-ICARDA (2017) Crop ecology, cultivation and uses of cactus pear (Eds. Ingles, P., Mondragon, C., Nefzaoui, A. and Saenz C.), p. 225, FAO, Rome, Italy

FAO-ICARDA (2017) Promoting cactus as an alternative and sustainable livestock feed. Food and Agricultural Organization, Rome, Italy

Gebremarian T, Melaku S, Yami A (2006) Effect of different levels of cactus (Opuntia ficus-indica) inclusion on feed intake, digestibility and body weight gain in tef (Eragrostis tef) straw-based feeding of sheep. Anim Feed Sci Technol 131:42-51
Guevara JC, Felker P, Balzarini MG, Páez SA, Estevez OR, Paez MN, de Coria C (2011) Productivity, cold hardiness and forage quality of spineless progeny of the Opuntia ficus-indica $1281 \times$ O. lindheimerii 1250 cross in Mendoza plain, Argentina. J Prof Assoc Cactus Dev 1: 48-62

Gushaa J, Halimani TE, Ngongoni NT, Ncube S (2015)Effect of feeding cactus-legume silages on nitrogen retention, digestibility and microbial protein synthesis in goats. Anim Feed SciTechnol 206: $1-7$

GushaaJ, Halimani TE, Katsandea S, Zvinorova PI (2015) The effect of Opuntia ûcus-indica and forage legumes based diets on goat productivity in smallholder sector in Zimbabwe. Small Rumin Res 125: $21-25$

Hanselka CW, Paschal JC (1990) Prickly pear cactus: an important rangeland resource. Prickly pear cactus: An important rangeland resource. Progress Report- Texas Agricultural Experiment Station. Beef Cattle Research in Texas, 1990: 141-143

ICAR- Central Sheep and Wool Research Institute (2017) Cactus: Ensuring round the year feed supply. Avikanagar, Rajasthan, India

IGFRI Vision-2050. ICAR- Indian Grassland Fodder Research Institute, Jhansi,Uttar Pradesh, India

Kauthale V, Aware M, Punde K (2017) Cactus an Emerging Fodder Crop of Arid and semi Arid India. BAIF Development Research Foundation, Central Research Station, Urulikanchan, Dist- Pune 412 202, Maharashtra, India

Khanum SA, Yaqoob T, Sadaf S, Hussain M, Jabbar MA, Hussain HN and Rehman S (2007) Nutritional evaluation of various feedstuffs for livestock production using in vitro gas method. Pak Vet J. 27: 129

Kumar K, Singh D, Singh RS (2018) Cactus pear: Cultivation and uses. ICAR- Central Institute for Arid Horticulture, Bikaner, Rajasthan, India

Kumar S, Ahmed S, Kumar TK, Palsaniya DR, Misra AK, Sarker A, Hassan S, Louhaichi M, Ghosh PK (2017) Initiative at IGFRI on Cactus Research. ICAR- Indian Grassland Fodder Research Institute, Jhansi,Uttar Pradesh, India

Le Houérou HN (1996) The role of cacti (Opuntia spp.) in erosion control, land reclamation, rehabilitation and agricultural development in the Mediterranean Basin. J Arid Environ 33: 135-159

Lima TJ, Ribeiro NL, Costa RG, de Medeiros GR, de Medeiros AN, de Sousa S, Lorenzo JM (2019) Optimizing the use of spineless cactus in the finishing diet of lambs: physicochemical properties and sensory characteristics of meat. J Sci Food Agric 99: 6241-6247

Lins S, Pessoa RAS, de Andrade Ferreira M, de Souza Campos JM, da Silva J, de Lima Silva J, Santos SA, de Barros Melo TT (2016) Spineless cactus as a replacement for wheat bran in sugar cane-based diets for sheep: intake, digestibility and ruminal parameters. Revista Brasileira de Zootecnia. doi.org/10.1590/S180692902016000100004

Lins SEB, Pessoa RA, Ferreira MA, Campos JMS, Silva JABA, Santos SA, Silva JL, Melo TTB, Chagas JCC (2017) Effect of replacing wheat bran with spineless cactus plus urea in sugarcane-based diets for sheep. Small Rumin Res 47: 516-525

Makkar HPS (2017) Cactus as fodder and beyond. Broadening Horizon. Feedipedia.Vol.40. Animal Production and Health Division, FAO, Rome, Italy

Menezes CMD, Schwalbach LMJ, CombrinckWJ, Fair MD, de Waal HO (2010) Effects of sun-dried Opuntia ûcus-indica on feed and water intake and excretion of urine and faeces by Dorper sheep. S Afr J Anim Sci 40: 491-494

Misra AK, Mishra AS, Tripathi MK, Chaturvedi OH, Vaithiyanathan S, Prasad R., Jakhmola RC (2006). Intake, digestion and microbial protein synthesis in sheep on hay supplemented with prickly pear 
cactus [Opuntia ficus-indica (L.) Mill.] with or without groundnut meal. Small Rumin Res 63: 125-134

Nefzaoui A, Ben Salem H (2001) Opuntia: A strategic fodder and efficient tool to combat desertification in the WANA region. Cactus (Opuntia species) as Forage (C. Mondragon and S. Perez; eds.). pp 73-90

Rekik M, Ben Salemb H, Lassouedb N, Chalouati H, Ben Salem I (2010) Supplementation of Barbarine ewes with spineless cactus (Opuntia ûcus-indica f. inermis) cladodes during late gestation-early suckling: Effects on mammary secretions, blood metabolites, lamb growth and postpartum ovarian activity. Small Rumin Res 90: 53-57

Russell CE, Felker P (1987) The prickly-pears (Opuntia spp., Cactaceae): a source of human and animal food in semiarid regions. Economic Botany 41: 433-445

Santos AOA, Batista AM, Mustafa A, Amorim GL, Guim A, Moraes AC, de Andrade R.(2010) Effects of Bermuda grass hay and soybean hulls inclusion on performance of sheep fed cactus-based diets. Trop Anim Health Prod 42: 487-494

Santos J, Cezar MF, de Sousa WH, Cunha M, Filho JMP, de Sousa DO (2011) Carcass characteristics and body components of Santa Inês lambs in feedlot fed on different levels of forage cactus meal. Revista Brasileira de Zootecnia 40: 2273-2279
Sawyer JE, Knox LA, Donart GB, Petersen MK (2001) The nutritive quality of cholla cactus as affected by burning. J Range Manag 249253

Shoop MC, Alford EJ, Mayland HF (1977) Plains pricklypear is a good forage for cattle. J Range Manag 30: 12-17

Singh Gajender, Dagar JC, Lal K, Yadav RK (2014) Performance of edible cactus (Opuntia ficus-indica) in saline environments. Indian J Agric Sci 84: 509-513

Sirohi SK, Karim SA, Misra AK (1997) Nutrient intake and utilization in sheep fed with prickly pear cactus. J Arid Environ 36: 161-166

Soni ML, Yadava ND, Kumar S, Roy MM (2015) Evaluation for growth and yield performance of prickly pear cactus (Opuntia ficus-indica (L.) Mill) accessions in hot arid region of Bikaner, India. Range Manage Agroforest 36: 19-25

Souza EJ, Guim A, Batista ÂM, Santos KL, Silva JR, Morais NAP, Mustafa AF (2009) Effects of soybean hulls inclusion on intake, total tract nutrient utilization and ruminal fermentation of goats fed spineless cactus (Opuntia ûcus-indica Mill) based diets. Small Rumin Res 85: 63-69 